\title{
加工熱処理シミュレータ*
}

\section{Thermo-mechanical Treatment Simulator}

\author{
綾田＼cjkstart倫彦**，東野 豊之**
}

\section{Michihiko AYADA • Toyoyuki HIGASHINO}

軽量化の観点から, 最近, 高強度・高勒性ばね材料の開発が望まれている。加工熱処理法 (T. M.T.)は, このような優れた機械的性質を得るための有効な手段のうちの 1 つである. 過去, 加 工熱処理の研究は行なわれてきたが, 加熱・冷却・加工を結びつけた優れた制御方法がなかっ たため，その効果を充分に引出せなかった。そこで，我々は加工熱処理のメカニズムを研究す る目的で, 新しく連続多段压縮を特徵としたコンパクトな加工熱処理シミュレー夕を開発した。 本装置は，他に“鍛造焼入れ”，“焼䍃し温間鍛造”などの加工熱処理法にも適用できる。本論 文は, このシミュレータの概要と T.T.A., T.T.T.やオースフォーミングに関する試験例につい てまとめたものである。本装置により，ばね鋼の機械的性質を改善するための適性な加工プロ 七スが見出さ礼る上思われる。

From the viewpoint of weiht saving, it has recently been required to develop highstrength and high-toughness spring steel. Thermo-mechanical treatment (T.M.T.) process would be one of the effective methods to achtieve high mechanical properties of spring steel. Although several studies have been making in this field, it was difficult to obtain the advantage of T.M.T. process, because of the difficulty to control the combination of heating, cooling and forming process effectively. A new compact type T.M.T. simulator based on cotinuous multi-step compression, was developed to study the mechanism of the T.M.T. process. It will be possible for this simulator to apply some different T.M.T. processes such as work-quenching and warm temper forging etc. This paper is mainly concerned with the outline of this simulator and some experimental results of T.T.A., T. T.T. diagrams and ausforming. By using this simulator, the appropriate process to improve mechanical properties of spring steel would be obtained.

\section{1. 緒 言}

近年，自動車懸架用ばねは軽量化に対するニーズか ら高強度・高勒性化が強く望まれている。

このための対策としては，(1)焼戻し硬さを向上させ る方法, (2) Mo, V などの強化元素を添加するなど新鋼 種の開発, 及び, 本報で言う(3)加工熱処理法の適用な どが考えられる.

(1)項に関しては, 耐へたり性の改善効果は認められ るものの靶性低下が問題となる。

(2)項に関しては，延性改善と耐へたり性向上の相反 する現象を満足する成分設計に苦虑しているのが現状 である。

(3)項に関しては，1960年代に最も基礎研究が多くな

原稿受付日 昭和 63 年 11 月 1 日

* ばね技術研究会 昭和 62 年度秋季講演会で発表

** 陎日発グループ中央研究所 (NHK SPRING R\&D CENTER INC.)
され，最近板ばねにおいてもモディファイド・オース フォーミングが再検討されている(1) 3).

一般に加工熱処理法は，加工の時期と利用する変態 により, 表 1 に示すような種々の加工法に分類される4).

ところが, 従来, 加工熱処理法の研究の進め方とし ては実機を用いることが多く，当然ながらこのように 数多くの加工法を検討することは装置性能上不可能で あった。

最近になり，広範囲の加工熱処理条件に対応すべく 大型のシミュレータが開発されている( ${ }^{5) ~ 8) . ~}$

これに対し，我々はコンパクト化，沉用性を主眼と した独自の連続多段压縮型の加工熱処理シミュレー夕 を開発した。

本報では，このシミュレータの概要と応用例として T.T.A., T.T.T.図の作成例とオースフォーミングに関 する基礎実験結果についてまとめた。 
表 1. 鋼の加工熱処理法の分類

\begin{tabular}{|c|c|c|c|c|}
\hline \multirow{2}{*}{ 加工 } & \multicolumn{2}{|c|}{ 拡北変您（フェライト，パーライト） } & \multicolumn{2}{|c|}{ 然拡芿变㷛（マルテンサイト） } \\
\hline & 粏! & 称 & 分 & 名 \\
\hline \multirow{2}{*}{ 変 照 前 $の$ 加 石 } & $\begin{array}{l}\text { 然定オーステナイト } \\
\text { 域での玒. }\end{array}$ & 制 御 压 还 & $\begin{array}{l}\text { 落定オーステナイト } \\
\text { 增での加工 }\end{array}$ & $\begin{array}{llll}\text { 锻 } & \text { 造 } & \text { 绫 } & \text { 入 } \\
\text { 茫 } & \text { 接 } & \text { 烍 } & \text { 入 }\end{array}$ \\
\hline & 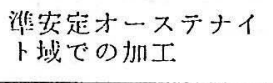 & & $\begin{array}{l}\text { 準安定オーステナィ } \\
\text { 卜域での加工 }\end{array}$ & オースフォーム \\
\hline 恋熊途中の扣工: & 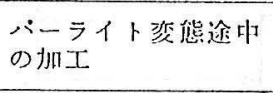 & アイソフォーム & $\begin{array}{l}\text { マルテンサイト恋㷛 } \\
\text { 途中の加工 }\end{array}$ & 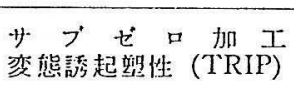 \\
\hline 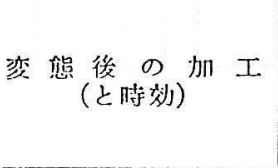 & ハーライトの加工 & パテンティング仲線 & $\begin{array}{l}\text { マルテンサイトの加 } \\
\text { エ }\end{array}$ & 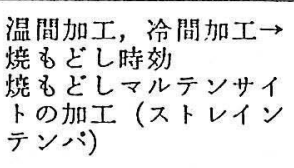 \\
\hline
\end{tabular}

\section{2. 加工熱処理シミュレータ装置の概要}

本シミュレータは, 油圧システムによる圧縮型の加 工装置を中心として, 高周波誘導加熱装置による加熱 系, 及び, 压縮空気を用いた泠却系の 3 ブロック, さ らに、これらの駆動・制御を行うパーソナル・コンピ ュータシステムから構成される。

図 1 に, 本シミュレータの外観, 表 2 に, 主な仕様, 図 2 に,ブロック図を示す.

本装置では, 油圧シリンダは $11 \mathrm{~kW} の$ 油圧ポンプと容 量 $30 l, \mathrm{~N}_{2}$ ガス封入圧 $14.7 \mathrm{MPa}$ の蓄圧型アキュムレー 夕 4 基により, 定格出力 $20.6 \mathrm{MPa}$, 吐出量 $600 \mathrm{l} / \mathrm{min}$ で 駆動される。

従って, 高速圧縮 (最大 $200 \mathrm{~mm} / \mathrm{sec}$ ), 連続多段压縮 (0.5secのインターバルにて 5 回まで連続圧縮)を可能 とし, 高速加工時の動的再結晶, 変形間時間における 静的再結晶, あるいは, 多段加工時の累積ひずみの効 果なども実験可能とした.

加熱装置は, 急速加熱を可能とするために定格 $20 \mathrm{~kW}$, $30 \mathrm{kHz}$ のサイリス夕位相制御方式・高周波誘導加熱装 置を用いた。この出力調整は, D/A 変換器を介しパー ソナル・コンピュータにより行われ，ロ7のSUP7 に対 して最大加熱速度で $300 \mathrm{~K} / \mathrm{sec} の$ 加熱能力がある。

なお，温度検出は $973 \mathrm{~K}$ 以下の低温域は 1 色放射温度 計, $973 \mathrm{~K}$ 以上 $1673 \mathrm{~K}$ 以下の高温域は 2 色放射温度計を 用い, 温度出力電圧は $\mathrm{A} / \mathrm{D}$ 変換器を介してパーソナル。 コンピュータに読取られる。

さらに, 冷却系としては超低温空気発生器 (エアーコ ルダー)と電空流量弁を組合せ, D/A 変換器を介してパ ーソナル・コンピュータにて弁の開放量を調節するこ とにより，冷却速度の制御を行う。この場合，圧縮空 気を供給することにより， ロ7の SUP 7 に対して最大 冷却速度は $100 \mathrm{~K} / \mathrm{sec}$ と臨界冷却速度以上の急速焼入 れが可能であった。

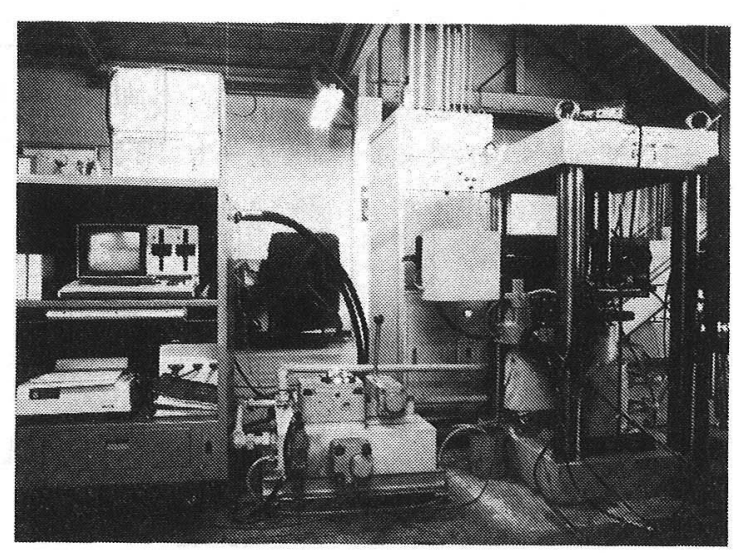

左から パソコン (PS・85), 油圧マニホールド, 加工 装置制御盤, 加工装置本体

図 1. 加工熱処理シュミレー夕外観

表 2. 加工熱処理シュミレータの主な仕様

\begin{tabular}{|c|c|}
\hline $\begin{array}{l}\text { 加熱方式 } \\
\text { 加 熱速 度 }\end{array}$ & 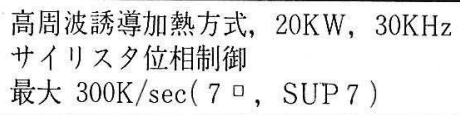 \\
\hline $\begin{array}{l}\text { 冷却方式 } \\
\text { 冷却速 度 }\end{array}$ & $\begin{array}{l}\text { 圧縮空気を超低温空気発生器を介して } \\
\text { 噴射, 流量は電空流量弁にて制御 } \\
\text { 最大 } 100 \mathrm{~K} / \mathrm{sec}(7 \text { 口, SUP 7) }\end{array}$ \\
\hline $\begin{array}{l}\text { 最大荷 重 } \\
\text { ピストンストローク } \\
\text { 压下速度 } \\
\text { 連続 压 繀 }\end{array}$ & $\begin{array}{l}294 \mathrm{KN} \\
\text { 最大 } 30 \mathrm{~mm} \\
\text { 最大 } 200 \mathrm{~mm} / \mathrm{sec}, \text { 最小 } 0.1 \mathrm{~mm} / \mathrm{sec} \\
\text { インターバル0.5 }\end{array}$ \\
\hline $\begin{array}{l}\text { 圧下量制 御 } \\
\text { 位置変更速度 }\end{array}$ & $\begin{array}{l}\text { DCサーボモータによるストッパー位置 } \\
\text { 回転制御 } \\
\text { 最大 } 5 \mathrm{~mm} / \mathrm{sec}\end{array}$ \\
\hline $\begin{array}{l}\text { 横移動量の制御 } \\
\text { 横 移動 速 度 }\end{array}$ & $\begin{array}{l}\text { DCサーボモータによるつかみ部のスラ } \\
\text { イド方式 } \\
\text { 最大 } 500 \mathrm{~mm} / \mathrm{sec}\end{array}$ \\
\hline 温度 検 出 & 2 色温度計及び 1 色温度計 \\
\hline
\end{tabular}




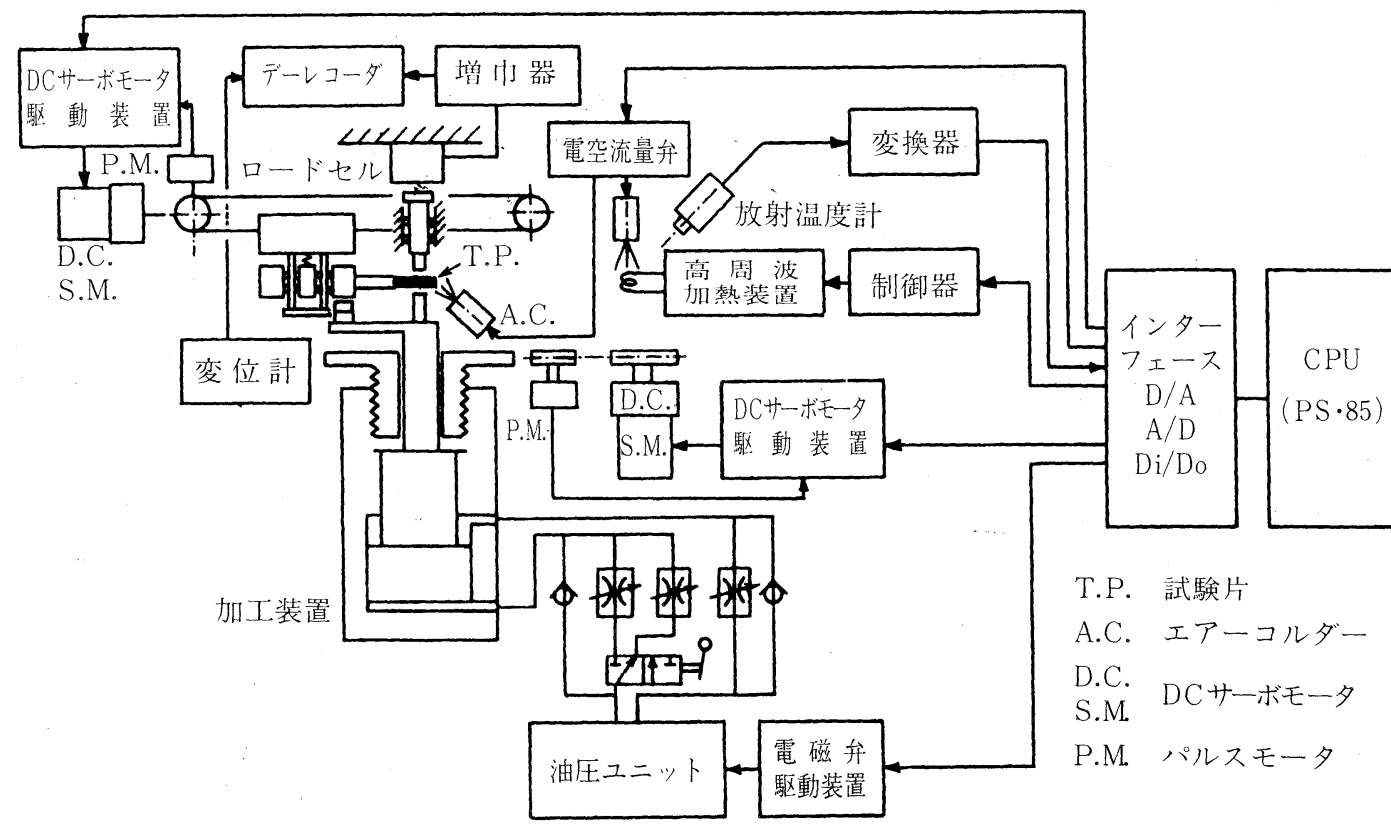

図 2.ブロック図

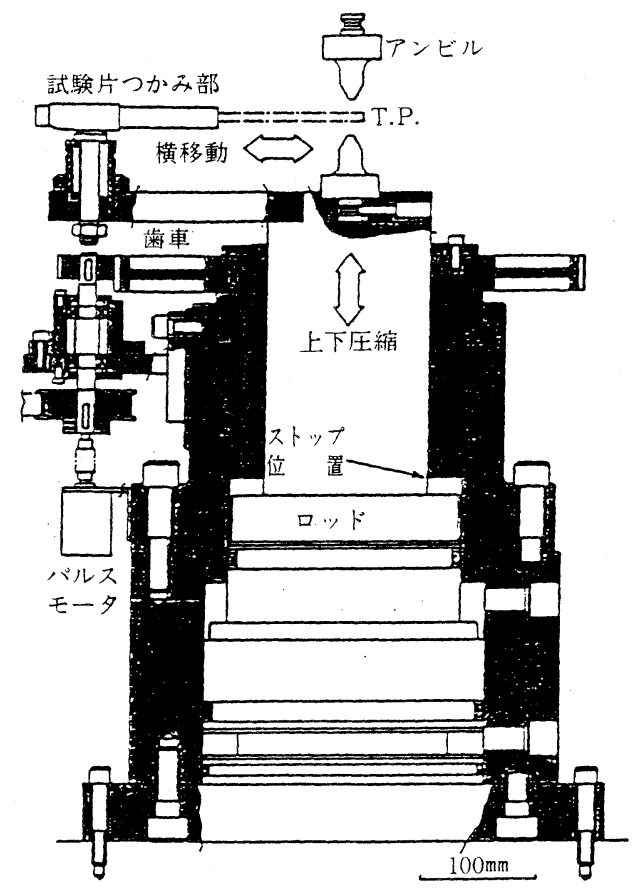

図 3．加工装置の主要部断面

図 3 は, 加工装置の主要断面を示すが, 圧下量の制 御は DCサーボモー夕により歯車を高速问転させて油圧 シリンダロッドのストップ位置を調整することによる。

これにより, 高速の压下量変更 (最大 $5 \mathrm{~mm} / \mathrm{sec}$ ) と高 精度の位置再現性をもたせている。

なお, 試験片の加工・加熱・冷却の 3 ゾーンへの横
移動は，スライドベアリング上をスライドする試験片 つかみ部を DCサーボモータで高速移動 $(500 \mathrm{~mm} / \mathrm{sec}$ ) することによっており, 圧下制御と共に $\mathrm{D} / \mathrm{A}$ 変換器を 介してパーソナル・コンピュータにて動作制御される. プログラム言語はべーシックを用いているが, 応答 性としては充分仕様を満足している。 


\section{3. 応用例}

\section{1 変態線図}

最近，急速加熱焼入れ・急速焼戻し処理したばね鋼 の高強度・高靸性化の報告もあり ${ }^{9), 10)}$, 急速加熱・冷却 時の変態挙動を把握することは重要である.

本シミュレータの応用として, 本来の加圧装置を静 止させることで例えば，急速加熱時のオーステナイト 化条件(T.T.A.図)，等温変態図(T.T.T.図)，連続冷却 变態図(C.C.T.図)などのいわば静的な变態挙動の探索に も応用は可能である。

図 4 は, SUP7 の T.T.A.図への応用例を示すもので, 急速加熱時に未溶解炭化物や未変態フェライトがなく, しかも，結晶粒の粗大化を起こさない適正なオーステ ナイト化条件が求められている。

また，図 $\mathbf{5}$ は，T. T. T.図への応用例を示寸が、才 一スフォーミングの際の比較データとして重要で，， 一ズの位置やべイの梁さ, 及び, パーライト変態, べ イナイト変態, マルテンサイト変態の開始と終了の条 件などが求まる。

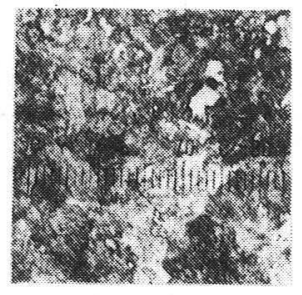

(a)未変態フェライト

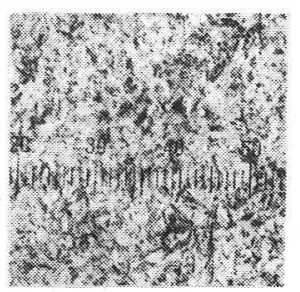

(b)均一マルテンサイト

3.2 オースフォーミング

\section{2 .1 ヒートパターンと加工特性}

本装置を用いて，“加工焼入れ”，“オースフォーミン グ”，“焼戻し温間加工” など各種の加工熱処理法がシ ミュレート可能であるが，ここでは，オースフォーミ ングへの適用例について報告する。

図 6 は,オースフォーミング時のヒートパターンの 測定例である。

この場合, オーステナイト化は 2 色放射温度計, 過 冷オーステナイト化は 1 色放射温度計で検出し, 加熱 制御は比例制御を用いている。

図中に，K熱電対による実測值も示したが，(a)部の オーステナイト温度での等温保持，(b)部の過冷オース テナイト温度へ過冷却を生ずることなく溸近し等温保 持している点など，急速加熱・冷却にもかかわらず基 本的なヒートパターンが精度良く得られている。

オースフォーミング時のアンビルと試験片の配置を 図 7 に示すが, 加圧面は約 $20 \mathrm{~mm} \times 10 \mathrm{~mm}$ である. また, 図 8 にオースフォーミング材のマクロ断面(ナ

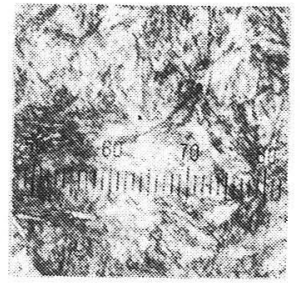

(c)結晶粒粗大化

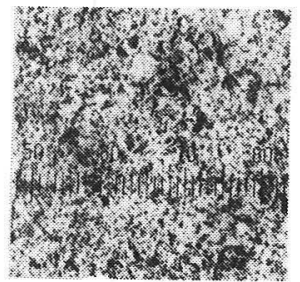

(d)未溶解炭化物

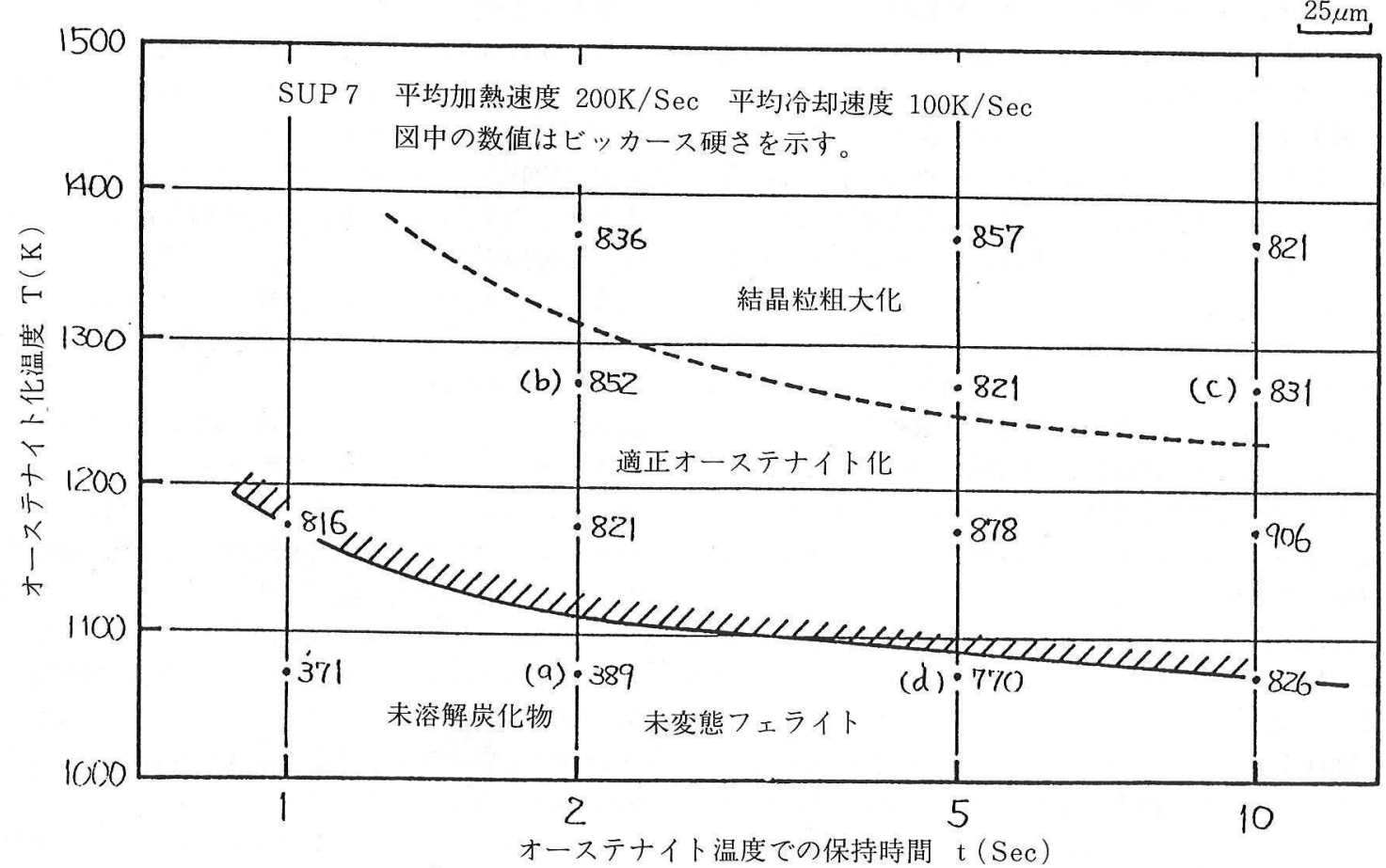

図 4.オーステナイト化条件 (T.T.A.図) への応用例 


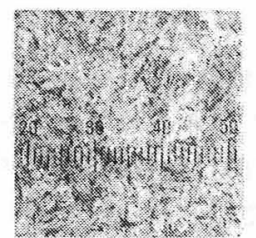

(a)マルテンサイト

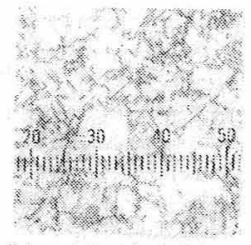

(b)ベイナイト変態初期

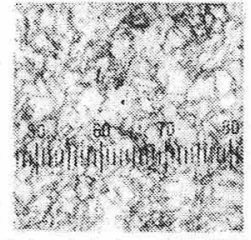

(c)ベイナイト変態後期

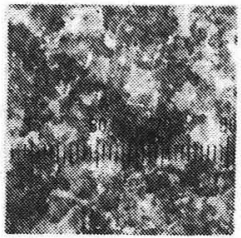

(d)フェライト+パーライト

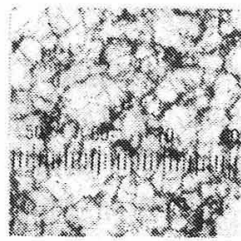

(e)上部ベイナイト

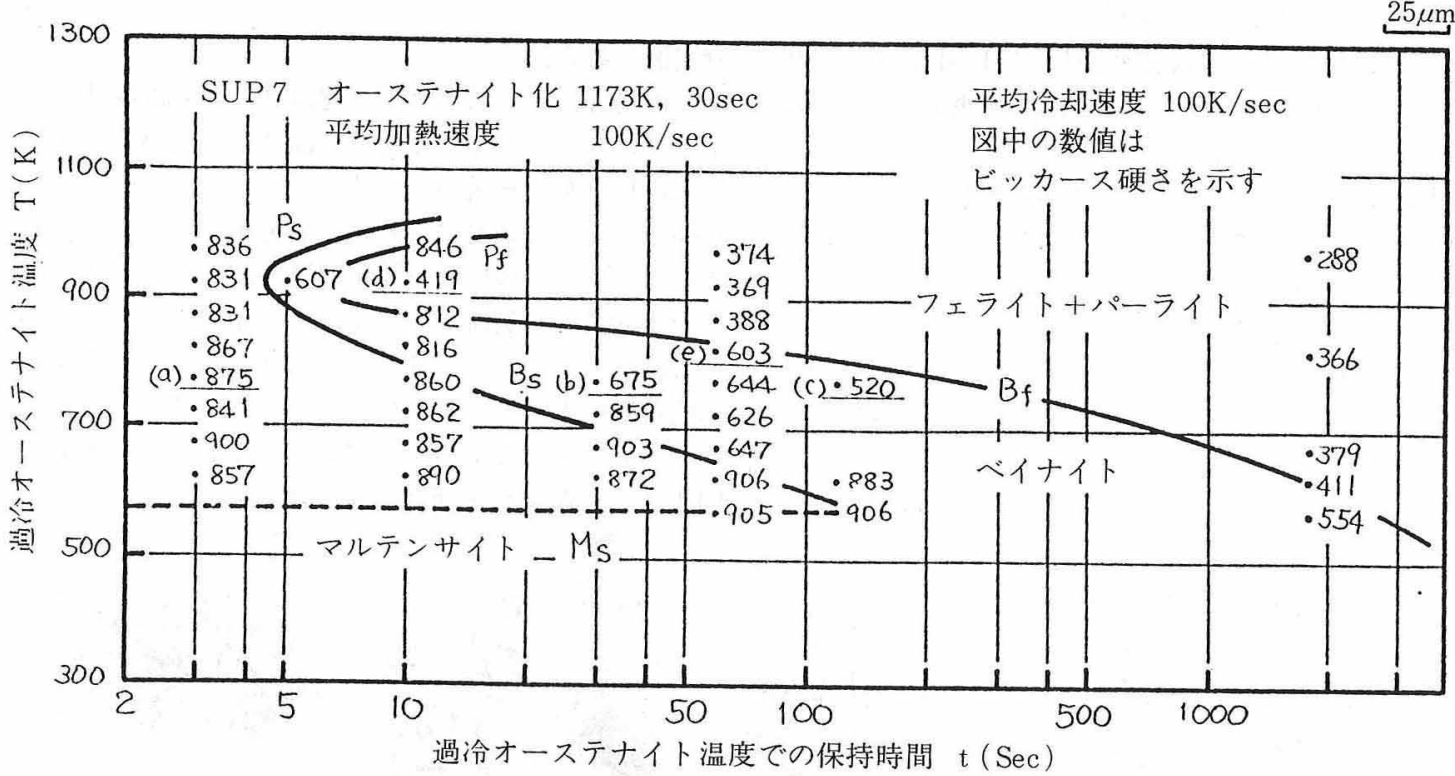

図 5.等温変態曲線への応用例

イタル腐食)を示すが, 圧縮型の特性としてアンビルの 圧下面直下には非変形域があり, 対角線上にすべり変 形帯が認められることから，加工ひずみの均一性の観 点からは問題が残る。

図 9 は, オースフォーミング時の荷重・変位の測定 例であるが，高速圧縮のため加工初期に衝撃による荷 重のピークが認められ，一定変位に保持中にも試験片 の熱収縮か再結晶によると思われるが動的に軟化を生 じている.

オースフォーミング時の変形応力は, 焼入れ直前の 加工硬化したオーステナイトを評価するために, 図中 に示したように除荷直前の荷重より求めた。

なお,一定変位の保持時間を短かくすることにより， 高速多段加工(変形間時間が約 $0.5 \mathrm{sec}$ ) ができ試験片の 長手方向の移動と組合せの断続的な加工ではあるが所 望長さの試験片が得られる。

図10，11に，オースフォーミング中の変形応力に及 ぼす加工度, 過冷オーステナイト保持時間と温度の影 響を示す。

図10より，オースフォーミング中の変形応力は圧下 率 $\mathrm{r}=36 \%$ 程度で最大となり圧下率 $\mathrm{r}=50 \%$ 程度では 36 \%に比べて低下している，従って，オーステナイトが 最も加工硬化する圧下率が36\%程度で，これより強圧
下を与えても動的再結晶により加工軟化が起こってい ると思われる ${ }^{11}$.

また，保持時間が長くなりべイナイト変態が始まり かけると変形応力が増加していることから, 所要荷重 を軽減し，十分に加工硬化したマルテンサイトを得る ためには短時間の保持が望ましい.

過冷オーステナイト温度が上昇するに従って, 図11 のように変形応力は低下するが, 変態を伴なうので後 述のようにオースフォーミング時には焼入れ後の硬さ が十分高くなるような温度を選定しなければならない。

\section{2 .2 硬さと組織}

図12は，オースフォーミング後の室温硬さに及ぼす 過冷オーステナイト化条件の影響をみたものである。

図中に，参考としてオースフォーミングと同一ヒー トパターンのマルクエンチ材を破線で示すが，過冷才 ーステナイト温度が低いほど，オースフォーミング材 とマルクエンチ材との硬さの差が大きい。

また，過冷オーステナイト温度での保持時間が長く なると硬さが低下していることから，過冷オーステナ イト領域でも安定状態は狭く, 変態が進行しているこ とがうかがえる.

なお，過冷オーステナイト温度 $873 \mathrm{~K}$, 保持 $20 \mathrm{sec}$ 以 上ではフェライト・パーライト変態を生じ急激に軟化 


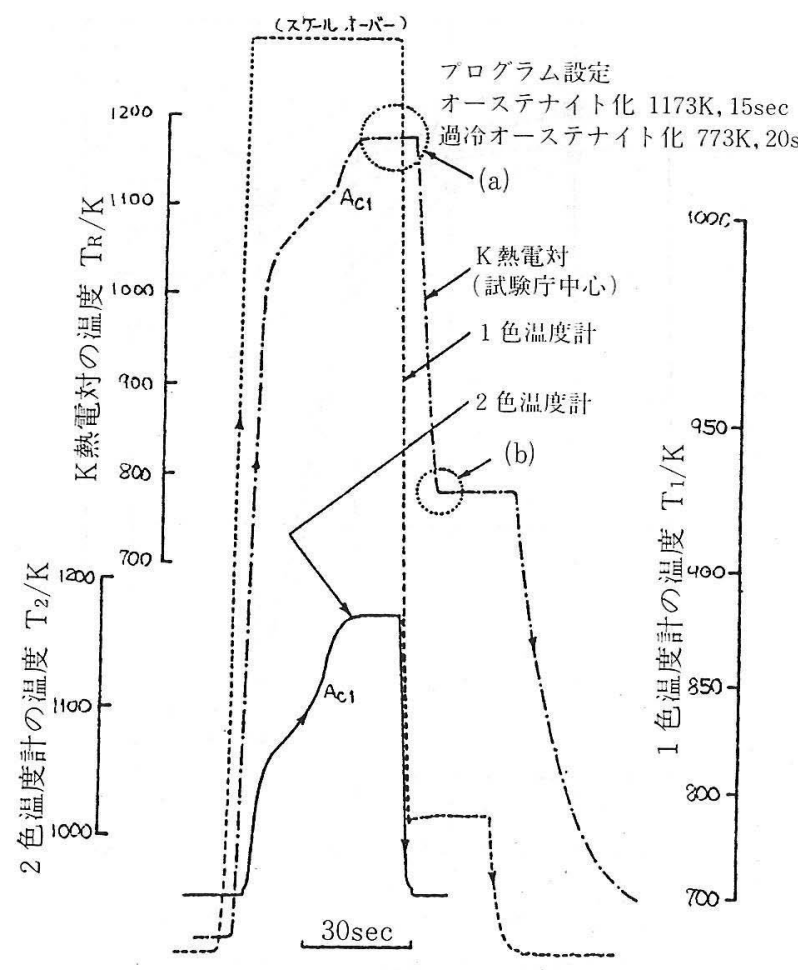

図 6.オースフォーミング時のヒートパターン測定例

オーステナイト化 $1223 \mathrm{~K}, 30 \mathrm{sec}$

適冷オーステナイト温度 $673 \mathrm{~K}$

過冷オーステナイト保持時間 $10 \mathrm{sec}$
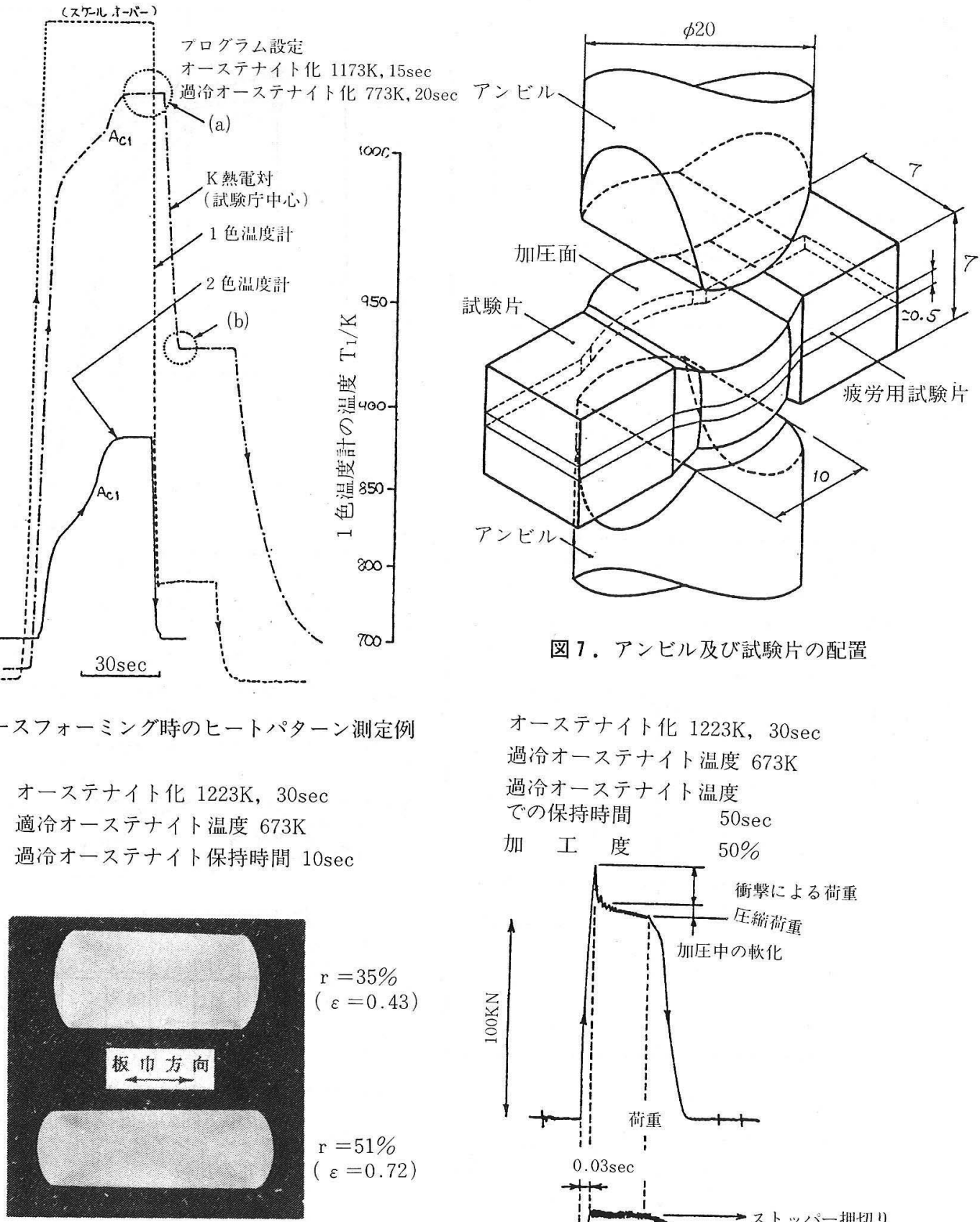

図 7.アンビル及び試験片の配置

オーステナイト化 $1223 \mathrm{~K}, 30 \mathrm{sec}$ 過冷オーステナイト温度 $673 \mathrm{~K}$ 過冷オーステナイト温度

での保持時間 $\quad 50 \mathrm{sec}$
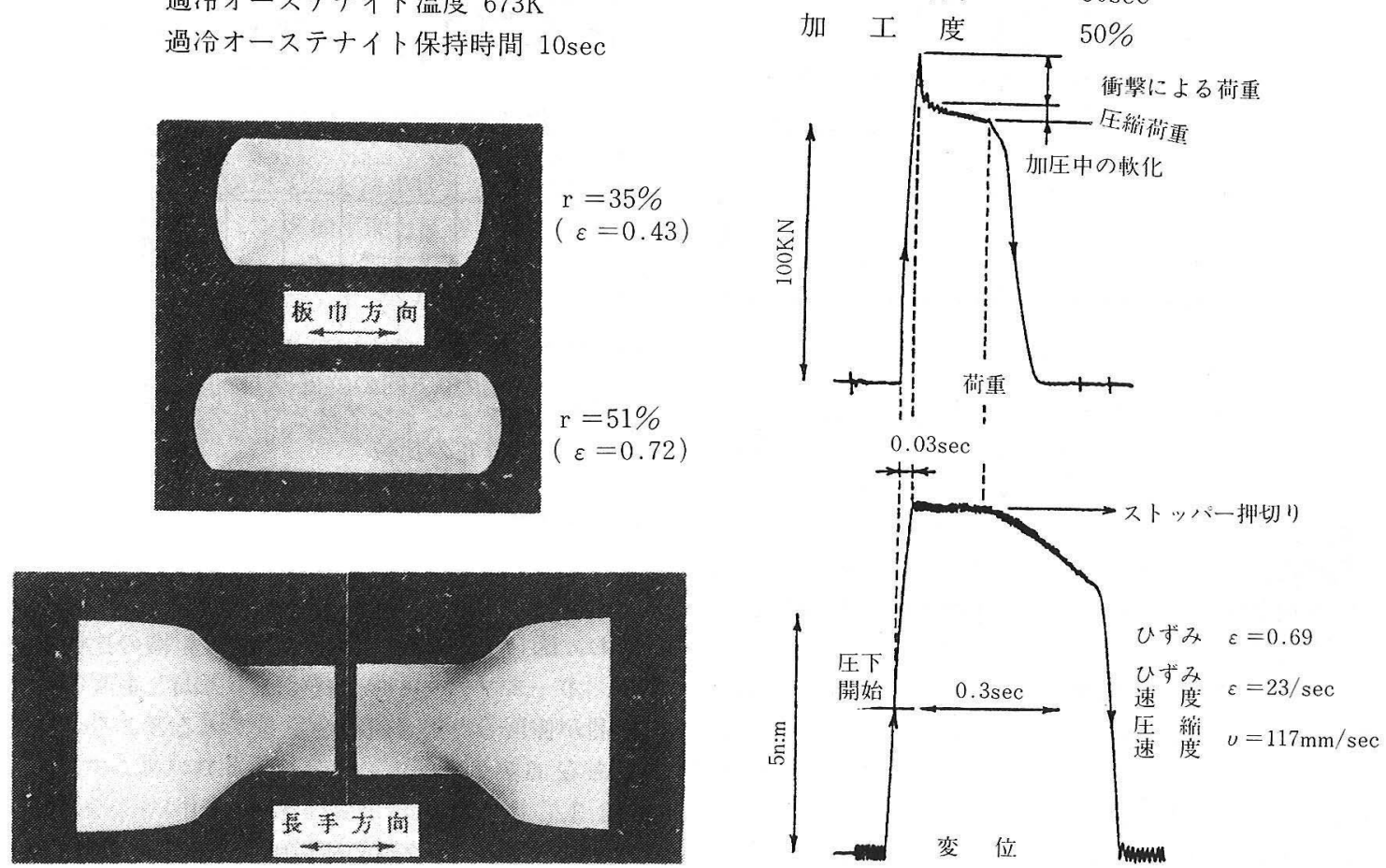

図 8.オースフォーミング材のマクロ断面

図 9・オースフォーミングにおける荷重・変位の測定 例 


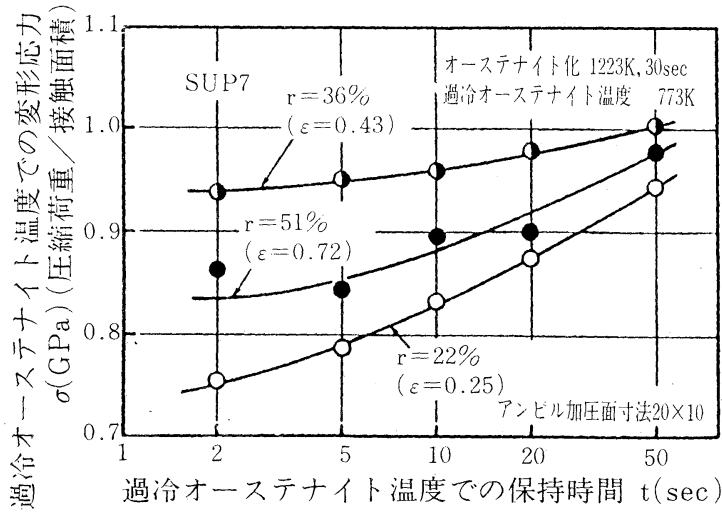

図10.オースフォーミング中の変形応力に及ぼす加工 度と保持時間の影響（過冷オーステナイト温度 $773 \mathrm{~K}$ )

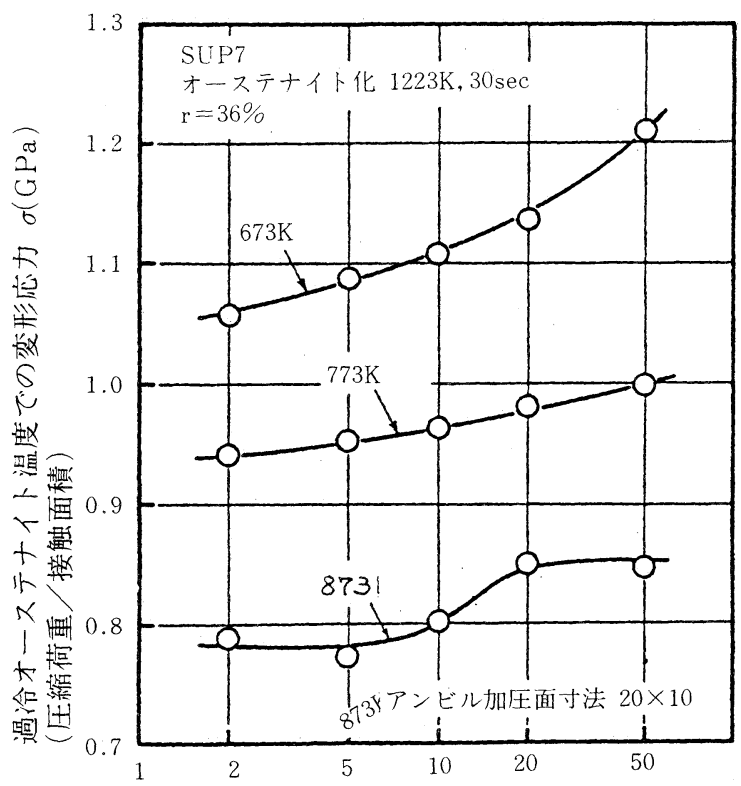

過冷オーステナイト温度での保持時間 $\mathrm{t}(\mathrm{sec})$

図11.オースフォーミング中の変形応力に及ぼす過冷 オーステナイト温度の影響（加工度 $36 \%$ ）

する。

図13は，オースフォーミング材とマルクエンチ材の 同一焼戻し条件での硬さ分布を板厚・板内方向で比較 したものである。

板厚方向では，圧下面直下に非変形域があるため， オースフォーミング材とマルクエンチ材で差は認めら れないが，加工ひずみの大きな板厚中心ではオースフ ォーミング材の方が硬い。

板巾方向では，板厚方向に比べると比較的硬さ分布 は平滑で，オースフォーミング材の方が硬く焼戻し軟 化抵抗が高いことがわかる。

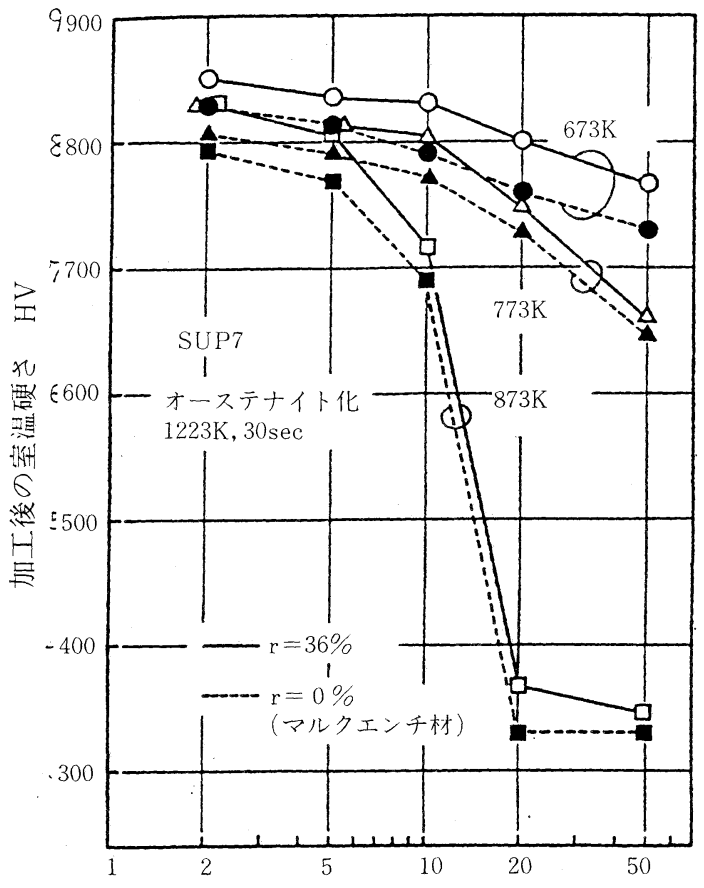

過冷オーステナイト温度での保持時間 $\mathrm{t}(\mathrm{sec})$

図12.オースフォーミング後の室温硬さに及ぼす過冷 オーステナイト条件の影響
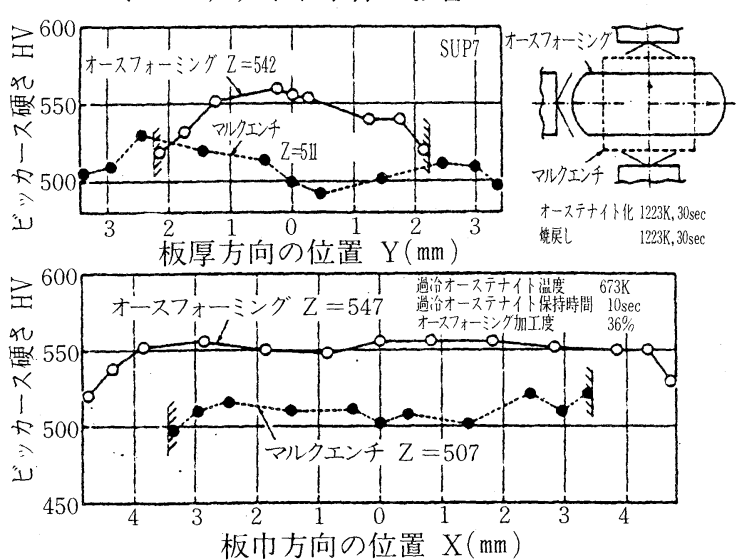

図13.オースフォーミング材とマルクエンチ材の焼戻 し硬さ分布の比較

以上を考虑して, 後述の薄板疲労試験においては硬 さ分布の均一な板巾方向の試験片を切出して製作した。 (図 7 参照)

なお，図14に，この時の光学顕微鏡組織の比較を示 すが，オースフォーミング材は圧下方向と垂直な方向 に結晶が伸展した集合組織を呈しているところが特徵 的である。

\subsection{3. 疲 労}

オースフォーミング材の疲労強度を確認する目的で, 図 7 に示した薄板試験片を用い, $3 \mu \mathrm{m}$ のアルミ十砥粒 でポリッシング加工を行った後，電磁加振疲労試験に 
$25 \mu m$

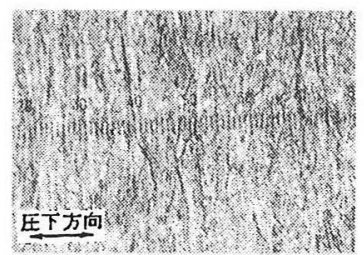

(a)オースフォーミング材

オーステナイト化 $1223 \mathrm{~K} 、 30 \mathrm{sec}$ 過冷オーステナイト温度 $673 \mathrm{~K}$ 適冷オーステナイト温度

での保持時間 10sec

オースフォーミング加工度 $36 \%$

燒 戻 L $723 \mathrm{~K}, 30 \mathrm{sec}$

図14.オースフォーミング材とマルクエンチ材の焼戻 し後の組織比較例

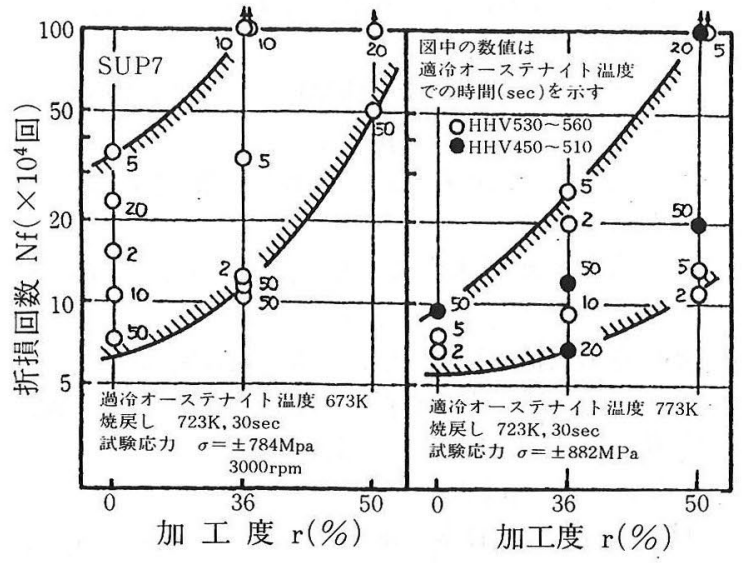

図15.オースフォーミング加工度と疲労寿命 供した。

図15に, 応力条件が各々 $\pm 784 \mathrm{MPa}, \pm 882 \mathrm{MPa}$ の場 合のオースフォーミング加工度と疲労寿命の関係を示 す.

薄板の場合, 試片のコーナ一面取りやセット精度な どの影響により折損回数はかなりばらついているもの の, 一般的な傾向としてはオースフォーミング加工度 が増加するほど高寿命の傾向が認められる。

オースフォーミング加工度と加工時の変形応力の関 係(図10)からみると, 加工度が36\%程度で最も加工硬 化が大きいことから疲労寿命もこの加工度近傍で極大 を示すのではないかと思われたが, 結果は50\%の方が 高寿命を示した。

ここでは，焼戻し後の硬さをほぼ同一にしており， 加工度の大きい方が加工集合組織の影響が強いためで はないかと思われるが, 今後, 試験数を増加し加工度 の効果をより明確にする必要がある。

図16は,ビッカース硬さを基準にオースフォーミン グ材と調質材の瘦学寿命を比較したものである。

一般的には, 硬さと共に疲労寿命は向上する傾向が
あり,ビッカース硬さが550以下では両者の差は殆ど見 られないのに対して,ビッカース硬さが 600 以上の高硬 さ域でオースフォーミング材の疲労強度が優れている ことがわかる。

画者の痩労破面の比較を図17に示すが，ほぼ同一の 焼戻し硬さであるにもかかわらず，オースフォーミン グ材は粒内破壊型の破面であり，調質材は粒界破壊型 の破面を呈している.

このことが, 高硬さ域での痩労寿命に影響している と思われ，オースフォーミングによって粒界が強化さ れ疲労き裂の伝ぱが遅れたためではないかと考えられ る.

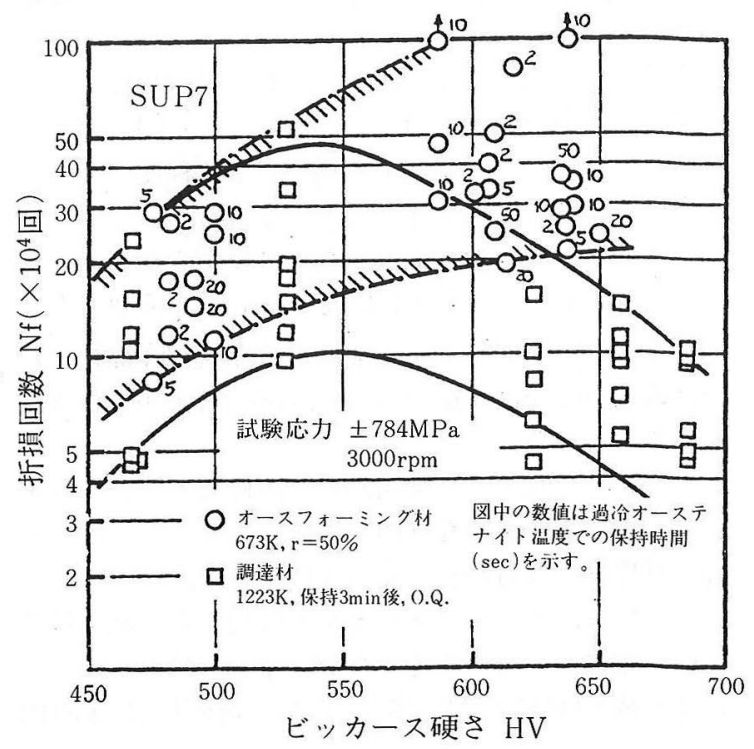

図16.オースフォーミング材と調質材の疲労寿命の比 較

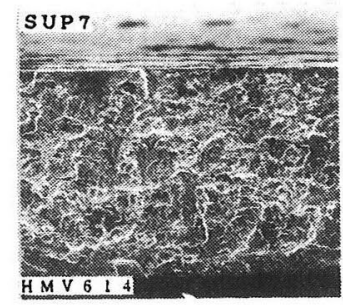

(a)オースフォーミング材 オーステナイト化 $1223 \mathrm{~K}, 30 \mathrm{sec}$ 過椧オーステナイト温度 $673 \mathrm{~K}$ 過泠オーステナイト温度 での保持時間 20sec オースフォーミング加工度 $50 \%$ 焼 戻 l $673 \mathrm{~K}, 30 \mathrm{sec}$
$100 \mu \mathrm{m}$

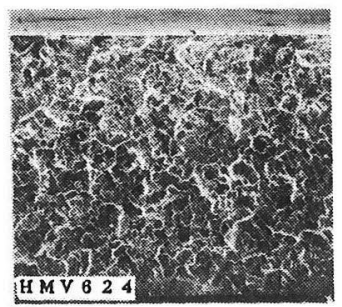

(b)普通調質材

オーステナイト化 $1223 \mathrm{~K}, 5 \mathrm{~min}$ 油焼入れ

焼 戻 L 673K, 45min
図17。薄板での疲労破面の比較 


\section{4. 結 言}

加工熱処理法は, 文字通り加工と熱処理の組合わせ であるから, 与える加工方法, 加工速度(ひずみ速度), 加工度 (ひずみ)はもとより, 加工時期が変態前なのか 変態中なのか変態後なのか, さらに利用する変態が拡 散変態か無拡散变態かにより得られる材質は全く異な り, 無数の可能性を秘めている.

ばねを取巻く環境をみると，軽量化に対するニーズ から更に材料の高強度化・高靸性化へ究極の材料開発 が求められており, 何らかの加工熱処理法により積極 的に材質改善を四る必要があるのではないだろうか。

幸いにして，近年，コンピュータによる制御技術の 急速な進歩により，従来は全く闲難とされていた技術 も身近なものになっている。

本報で述べた加工熱処理シミュレータは可能な限り 多くの加工熱処理法に対処できることを主眼に, かつ, パーソナル・コンピュータで操作できる程度のコンパ クトさを特徵として製作したものである.

もちろん，压縮型であるこためにひずみが不均一と なる点, 加工ひずみ速度が最大 $50 / \mathrm{sec} て ゙$ 高速加工まで は完全にシミュレート不可能である点(現在, 線材圧延 では最大 $500 / \mathrm{sec} に$ に達するものもある.)など不充分な点 も残されている。

しかし，それまでの加工熱処理の研究方法と比較す ると, 影響因子をかなり明確に区別することが可能と なり基礎的な検討が行えるようになった。

本報では，オースフォーミングに関する一部の基礎 実験結果についてのみ述べなが，オースフォーミング による疲労強度の向上に関しては, 今後さらに金属組
織学的にも詳細な検討が必要である。

また，鍛造焼入れ，焼戻し温間鍛造など他の加工熱 処理法に関しても本シュミレータによる検討を行い， 高強度・高靱性ばね材料を得るための適正な加工プロ セスを見出したいと考えている.

\section{参 考 文 献}

1 ）小曽根敏夫, 川越誠，ばね技術研究会昭和 62 年 度 春季講演会前刷集, (1987), p.5.

2 ）杉本淳, 田中達夫, 脇門惠洋, 大木喬夫, ばね 技術研究会昭和62年度秋季講演会前刷集, (1987), p.5.

3 ）尾崎克彦, 西岡克幸, ばね技術研究会昭和 63 年 度春季講演会前刷集, (1988), p.24.

4 ) 牧正志, 田村今男, 塑性と加工, Vol. 25, No. 284, (1988), p.772.

5 ）矢田浩，松津伸彦，関根寛，二村忠，鉄と鋼， 80- S 992, (1980), p.392.

6 ）大北智良, 新倉正和, 日本鋼管報, No. 101, p. 117, (1984).

7 ）横井玉雄, 美坂佳助, 鉄と鋼, '83-S 466, (1983), p. 150 .

$8 ）$ 電気製鋼, Vol. 54, No. 3, (1983), p.220.

9 ）川寄一博, 千葉貴世, 山崎隆雄, 鉄之鋼, 第74 年, 第 2 号, (1988), p.128.

10) 同上, p.136.

11）田村今男, 日本金属学会会報, Vol. 20, No. 12, (1981), p.987. 